\title{
Use of topical dorzolamide for patients with X-linked juvenile retinoschisis: case report
}

\author{
Uso da dorzolamida tópica em pacientes com retinosquise juvenil \\ ligada ao $X:$ relato de caso
}

\author{
André Luís Carvalho de Moura Bastos ${ }^{1}$ \\ Bruno de Paula Freitas ${ }^{2}$ \\ Oscar Villas Boas ${ }^{3}$ \\ Alexandre Campelo Ramiro ${ }^{4}$
}

\begin{tabular}{|l|}
\hline ABSTRACT \\
\hline X-linked juvenile retinoschisis (XLRS) is a recessively inherited vitreore- \\
tinal degeneration characterized by macular pathology and splitting of the \\
neuroretinal layers that is associated with alterations in the XLRS1 gene. \\
There have been no therapeutic interventions known to be effective for \\
patients with X-linked juvenile retinoschisis, but some studies are trying \\
to determine the importance of dorzolamide for the treatment of foveal \\
lesions in this disease. The authors, using optical coherence tomography, \\
describe findings in a patient with X-linked juvenile retinoschisis, before \\
and after a topical use of dorzolamide. Besides the improvement in his \\
visual acuity, further studies are required to elucidate the real prevalence \\
of nonresponse to dorzolamide and the frequency with which there may \\
be a recurrence of foveal cystic changes during continued treatment.
\end{tabular}

Keywords: Retinoschisis; Retinal degeneration; Macular degeneration; Tomography, optical coherence; Carbonic anhydrase inhibitors/therapeutic use; Human; Male; Adolescent; Case reports [Publication type]

\section{INTRODUCTION}

X-linked juvenile retinoschisis (XLRS; OMIM 312700), also known as congenital cystic retinal detachment or congenital retinoschisis is a relatively rare disease, characterized by vitreous degeneration and splitting of the retina between the nerve fiber and ganglion cell layers. It is the most common cause of juvenile macular degeneration in males. The patients have typically a cystic-like stellate maculopathy or a foveal schisis ${ }^{(1-6)}$. Estimations of its prevalence range from 1:5000 to 1:25 000. Affected males have deterioration in vision which typically presents between 5 and 10 years of age $^{(4)}$. Visual impairment is usually mild until the fourth decade of life, but thereafter progressive visual deterioration often occurs ${ }^{(4-5)}$. Complications in the later stages of XLRS include vitreal hemorrhage, choroidal sclerosis, retinal detachment and, in rare cases, retinal atrophy resulting in blindness. There is a great intrafamilial variation in severity. Mild and severe forms of the disease may occur in one family ${ }^{(4)}$. A distinctive feature of this disease is a selective or predominant b-wave amplitude reduction shown by electroretinography.

Optical coherence tomography (OCT) is a new imaging technique that can provide high-resolution cross-sectional images of the macular region. In individuals with XLRS, OCT reveals multiple levels of schisis ${ }^{(7)}$. With the advent of OCT it is possible to explore retinal structures in clinical patients by a noninvasive imaging and to characterize forms of deeper retinal pathology. The typical cystic maculopathy of X-linked retinochisis has previous- 
ly been examined and characterized by OCT and demonstrated to involve the deeper retinal layers ${ }^{(8)}$.

The use of carbonic anhydrase inhibitor has been shown to be effective for the improvement of cystoid macular edema in some patients with retinitis pigmentosa ${ }^{(9-11)}$ and some authors are trying to show the efficacy of topical dorzolamide for treating foveal cystic-appearing lesions in patients with $\mathrm{XLRS}^{(12)}$.

We report a case of a patient with X-linked juvenile retinoschisis that was submitted to optical coherence tomography before and after treatment with topical dorzolamide.

\section{CASE REPORT}

A 12-year-old male patient came to the Retina and Vitreous Outpatient Clinic of IBOPC complaining of a progressive visual acuity loss in both eyes. The symptom was present for 4 years and had worsened in the past 2 years. He also noticed an uncle and a cousin with the same symptom. He had no previous history of trauma, inflammatory or infectious ocular disease.
Ophthalmologic examination disclosed best corrected visual acuity of 20/80 in the right eye and 20/100 in the left eye. Ocular mobility and anterior segment biomicroscopy was normal. Applanation (Goldmann) tonometry recorded $10 \mathrm{mmHg}$ in both eyes.

On indirect ophthalmoscopic fundus examination, the patient had the typical stellate maculophaty of radiating cystoid spaces, also known as spoke wheel-like maculopathy (Figure 1). Fluorescein angiography showed accumulation of dye in the cystoid spaces in the left eye (Figure 2).

During investigations he was examined with ultrasonography, that was normal, and OCT (Zeiss Humphrey OCT 1, upgraded version). The OCT results revealed a pattern with a cleavage of the retina into two distinct planes, one deep (outer retina) and one superficial. The two layers were superficially connected with thin-walled, vertical palisades, separated by low reflective, cystoid spaces, which were confluent and most prominent in the foveal region (Figure 3).
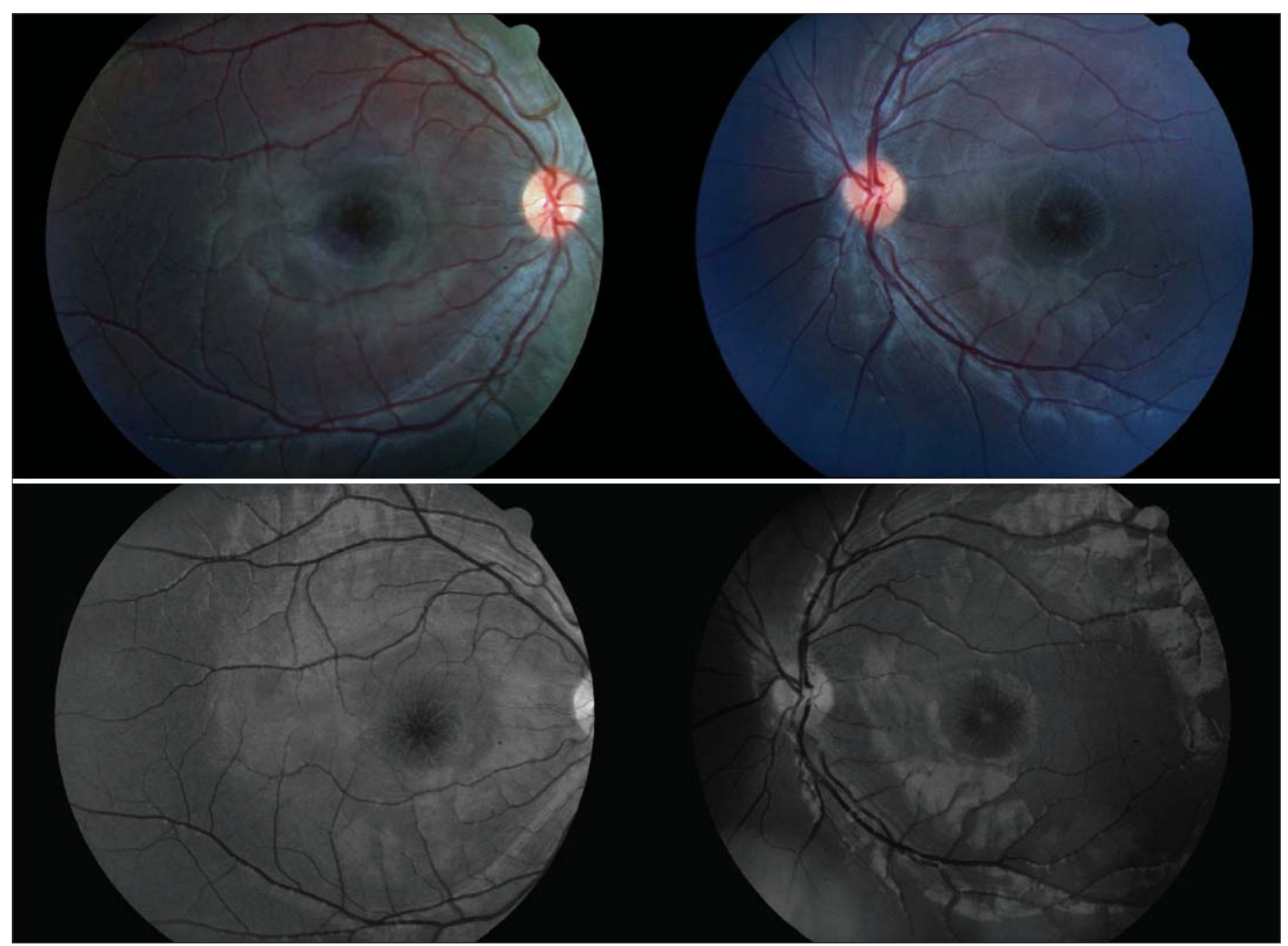

Figure 1 - Spoke wheel-like maculopathy 


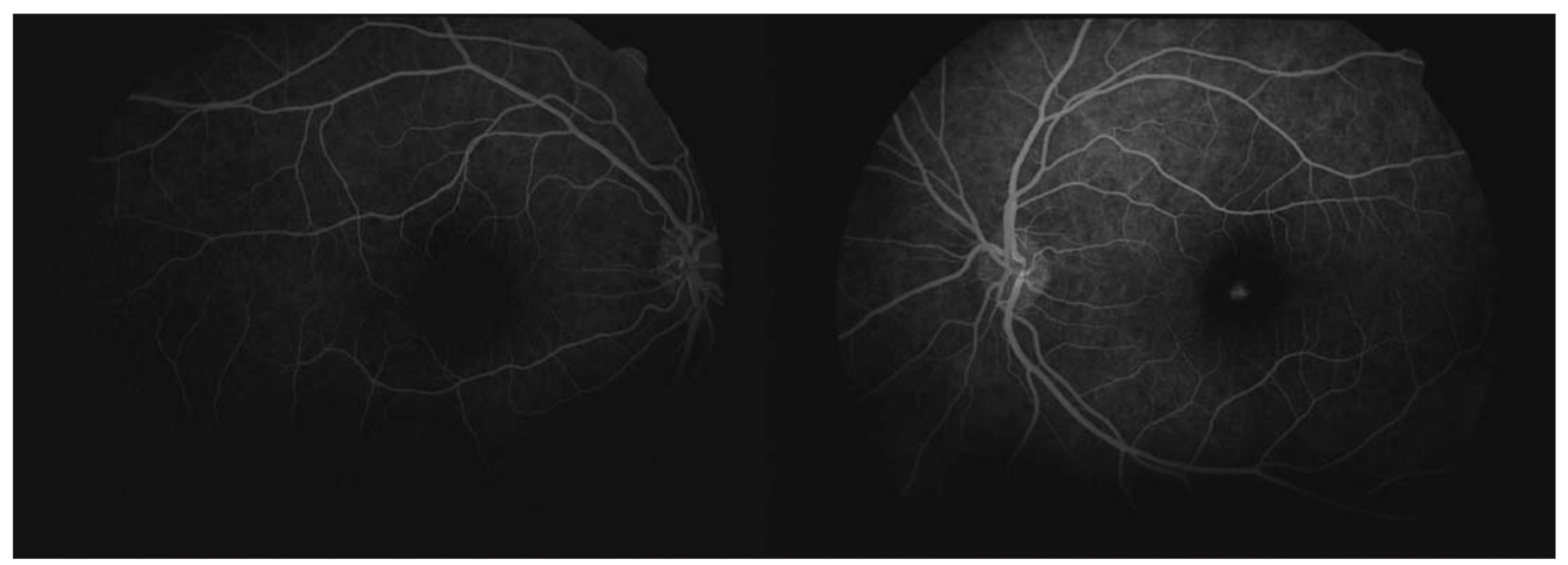

Figure 2 - Fluorescein angiography showing accumulation of dye in the cystoid spaces in the left eye
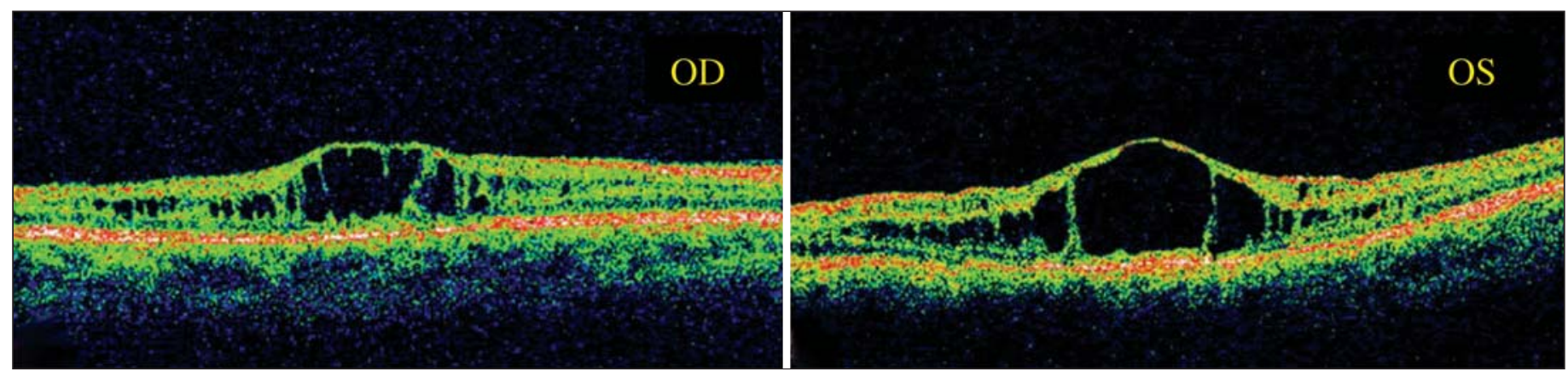

Figure 3 - OCT pretreatment

The patient was assigned to use $2 \%$ dorzolamide, three times daily in each eye for 60 days. The patient returned in 30 and 60 days for repeated best-corrected visual acuity and OCT measurements, which showed a substantial improvement in the visual acuity in the left eye and in the degree of his foveal cystic-appearing lesions in both eyes (Figures 4, 5).

\section{DISCUSSION}

$\mathrm{X}$-linked juvenile retinoschisis is characterized by decreased visual acuity in the first decade of life and a splitting of the sensory retina, with cyst formation between the two resultant layers. It is slowly progressive, and most patients retain relatively good vision until the fifth or sixth decades of life, when macular atrophy develops. On average, visual acuity is around $20 / 60$ at age 20 , gradually declining to $20 / 200$ by age 60 , usually as a result of macular changes ${ }^{(13)}$. Histologically, the disorder is characterized by coalescent cysts, which are located primarily in the outer plexiform and adjacent nuclearlayers of the retina. Nonunion of the retinal layers results in a retinoschisis cavity. This produces a translucent, veil-like membrane extending into the vitreous. The cyst is typically located in the inferotemporal quadrant of the ocular globe. Foveal schisis is characteristic of juvenile retinoschisis, occurring in $98 \%$ to $100 \%$ of patients. Although macular changes are present in all affected patients, some investigators have found the typical foveal schisis ("stellate maculopathy") to be present in only $70 \%$ of the patients ${ }^{(14)}$.

The physiological mechanism of congenital retinoschisis involves inherently weak Müller cell pillars. The Müller cell, the principal glial cell of the retina, is central to the migration and organization of other retinal cells during development. A gene defect in the Müller cell could account for the structural and physiological abnormalities found in juvenile retinoschisis ${ }^{(1)}$. Mutation of a single gene, $\mathrm{RS} 1$, has been described in patients affected with this disease $^{(15)}$. The gene produces a 224 amino acid soluble secretory protein, retinoschisin, that is synthesized in photoreceptor inner segments and provides cell adhesion and proper interaction between cells within the inner nuclear layer as well as synaptic connections between bipolar cells and photoreceptors ${ }^{(16)}$. In patients with XLRS, a dysfunction in this protein leads to the accumulation of retinoschisin within the inner retina and the development of cys- 

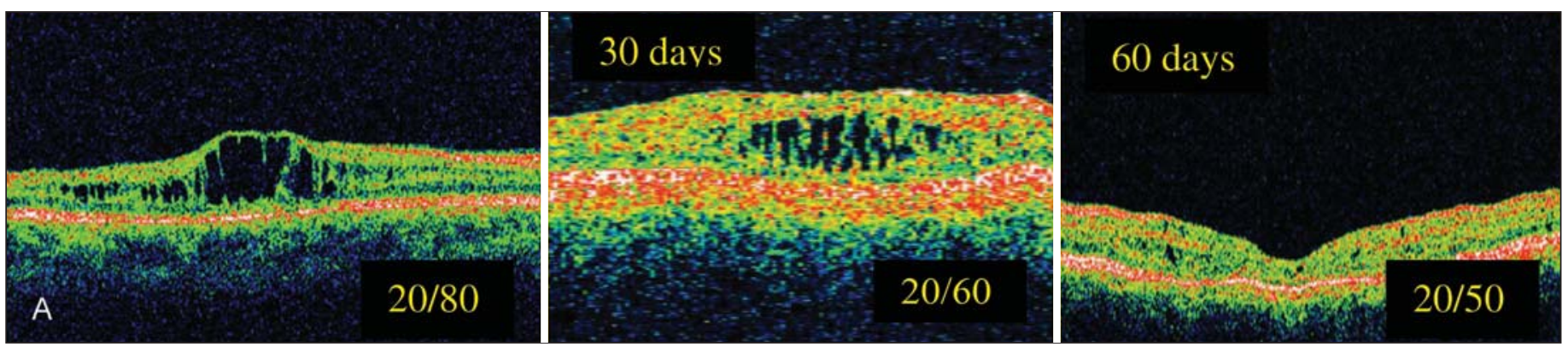

Figure 4 - OCT right eye postreatment
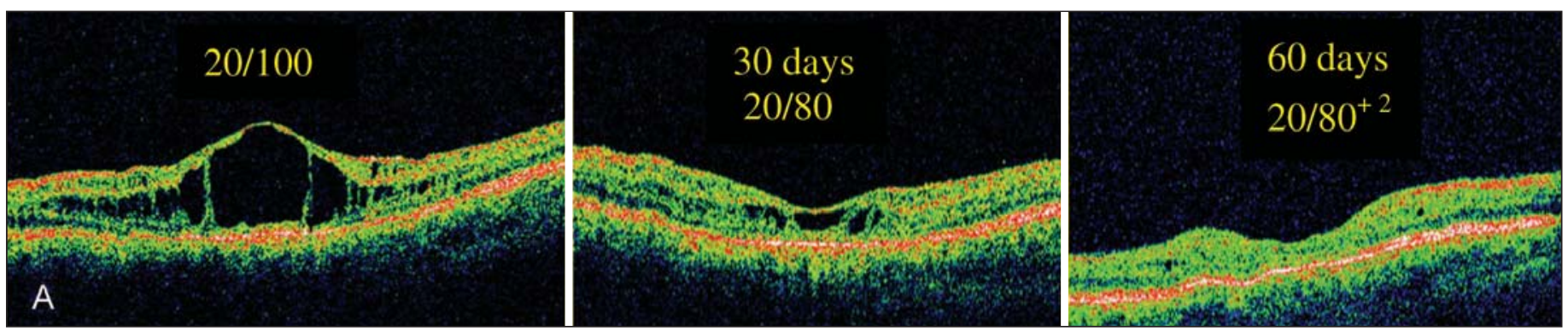

Figure 5 - OCT left eye postreatment

tic-like spaces primarily in the inner nuclear and outer plexiform layers of the retina observed by $\mathrm{OCT}^{(17-18)}$.

Our findings document that the foveal cystic-appearing lesions may favorably respond to the treatment with topical carbonic anhydrase inhibitors. A precise explanation for such a favorable response is not readily apparent. However, it is possible that the cystic spaces in the fovea apparent by OCT represent the accumulation of soluble retinoschisin, which, with the use of dorzolamide, undergoes resorption, likely facilitated by retinal pigment epithelium cells. It is also conceivable that continued treatment with dorzolamide could result in an even further improvement of visual acuity to a greater extent $^{(12)}$.

Nevertheless the improvement in visual acuity of our patient and the excellent aspect of OCT after treatment with topic dorzolamide, show that further studies are required to elucidate the real prevalence of nonresponse to dorzolamide and the frequency with which there may be a recurrence of foveal cystic changes in a long-time of treatment.

\section{RESUMO}

A retinosquise juvenil ligada ao X (XLRS) é uma degeneração vítreo-retiniana hereditária e recessiva caracterizada por lesão macular e delaminação das camadas de fibras nervosas da retina, que está associada com alterações no gene XLRS1. Nenhuma intervenção terapêutica tem se mostrado efetiva em pacientes com retinosquise juvenil ligada ao $\mathrm{X}$, mas alguns estudos estão tentando determinar a importância da dorzola- mida no tratamento das lesões foveais desta doença. Os autores, usando a tomografia de coerência óptica, descrevem os achados em um paciente com retinosquise juvenil ligada ao $\mathrm{X}$, antes e após o uso de dorzolamida tópica. Apesar da melhora na acuidade visual do paciente estudado, outros estudos são necessários para uma melhor elucidação da real prevalência dos pacientes não responsivos ao tratamento com dorzolamida, bem com a recorrência das lesões císticas a longo prazo.

Descritores: Retinosquise; Degeneração retiniana; Degeneração macular; Tomografia de coerência óptica; Inibidores da anidrase carbônica/uso terapêutico; Humano; Masculino; Adolescente; Relatos de casos [Tipo de publicação]

\section{REFERENCES}

1. Forsius H, Krause U, Helve J, Vuopala V, Mustonen E, Vainio-Mattila B, et al. Visual acuity in 183 cases of X-chromosomal retinoschisis. Can J Ophthalmol. 1973;8(3):385-93.

2. de la Chapelle A, Alitalo T, Forsius H. X-linked juvenile retinoschisis. In: Wright A, Jay B, editors. Molecular genetics of inherited eye disorders. Switzerland: Harwood Academic; 1994. p.339-57.

3. Kellner U, Brummer S, Foerster MH, Wessing A. X-linked congenital retinoschisis. Graefe's Arch Ophthalmol. 1990;228(5):432-7. Comment in: Graefes Arch Clin Exp Ophthalmol. 1991;229(5):497.

4. George ND, Yates JR, Moore AT. X linked retinoschisis. Br J Ophthalmol. 1995;79(7):697-702.

5. George ND, Yates JR, Moore AT. Clinical features in affected males with Xlinked retinoschisis. Arch Ophthalmol. 1996;114(3):274-80.

6. Deutman AF. Sex-linked juvenile retinoschisis. In: Deutman AF, editor. The hereditary dystrophies of the posterior pole of the eye. Springfield, Il: Thomas; 1971. p.48-98. 
7. Greene JM, Shakin EP. Optical coherence tomography findings in foveal schisis. Arch Ophthalmol. 20041;122(7):1066-7.

8. Azzolini C. Pierro L, Codenotti M, Brancato R. OCT images and surgery of juvenile macular retinoschisis. Eur J Ophtalmol. 1997;7(2):196-200.

9. Cox SN, Hay E, Bird AC. Treatment of chronic macular edema with acetazolamide. Arch Ophtalmol. 1988;106(9):1190-5.

10. Fishman GA, Gilbert LD, Fiscella RG, Kimura AE, Jampol LM. Acetazolamide for treatment of chronic macular edema in retinitis pigmentosa. Arch Ophtalmol. 1989;107(10):1445-52.

11. Grover S, Fishman GA, Fiscella G, Adelman AE. Efficacy of dorzolamide hydrochloride in the management of chronic cystoid macular edema in patients with retinitis pigmentosa. Retina. 1997;17(3):222-31.

12. Apushikin MA, Fishman GA. Use of dorzolamide for patients with X-linked retinoschisis. Retina. 2006;26(7):741-5. Erratum in: Retina. 2007;27(1):128.

13. Rosenfeld PJ, Flynn HW Jr, McDonald HR, Rubsamen PE, Smiddy WE,
Sipperley JO, et al. Outcomes of vitreoretinal surgery in patients with Xlinked retinoschisis. Ophthalmic Surg Lasers. 1998;29(3):190-7.

14. Yanoff M, Kertesz Rahn E, Zimmerman LE. Histopathology of juvenile retinoschisis. Arch Ophthalmol. 1968;79(1):49-53.

15. Sauer CG, Gehrig A, Warneke-Wittstock R, Marquardt A, Ewing CC, Gibson $\mathrm{A}$, et al. Positional cloning of the gene associated with $\mathrm{X}$-linked juvenile retinoschisis. Nat Genet. 1997;17(2):164-70.

16. Reid SNM, Yamashita C, Farber DB. Retinoschisin, a photoreceptor-secreted protein, and its interaction with bipolar and müller cells. J Neurosci. 2003; 23(14):6030-40.

17. Ozdemir H, Karacorlu S, Karacorlu M. Optical coherence tomography findings in familial foveal retinoschisis. Am J Ophathalmol. 2004;137(1):179-81. Comment in: Am J Ophthalmol. 2004;137(6):1157; author reply 1157.

18. Brucker AJ, Spaide RF, Gross N, Klancnik J, Noble K. Optical coherence tomography of X-linked retinoschisis. Retina. 2004;24(1):151-2. 